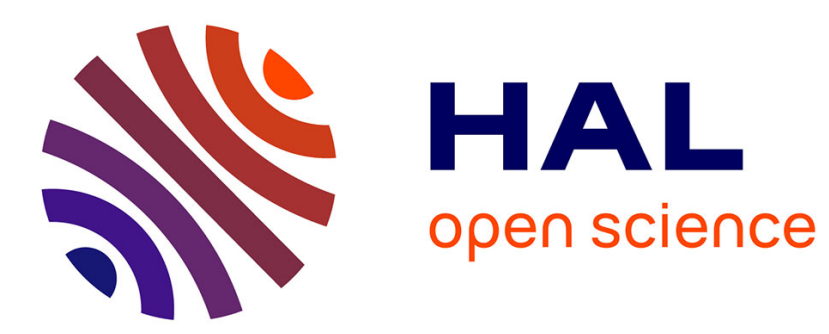

\title{
The Careful Balance of Gender and Sexuality: Rural Gay Men, the Heterosexual Matrix, and "Effeminophobia"
}

\author{
Alexis Annes, Meredith Redlin
}

\section{- To cite this version:}

Alexis Annes, Meredith Redlin. The Careful Balance of Gender and Sexuality: Rural Gay Men, the Heterosexual Matrix, and "Effeminophobia". Journal of Homosexuality, 2012, 5, pp.83 - 288. 10.1080/00918369.2012.648881 . hal-01564761

\section{HAL Id: hal-01564761 \\ https://hal.science/hal-01564761}

Submitted on 20 Sep 2017

HAL is a multi-disciplinary open access archive for the deposit and dissemination of scientific research documents, whether they are published or not. The documents may come from teaching and research institutions in France or abroad, or from public or private research centers.
L'archive ouverte pluridisciplinaire HAL, est destinée au dépôt et à la diffusion de documents scientifiques de niveau recherche, publiés ou non, émanant des établissements d'enseignement et de recherche français ou étrangers, des laboratoires publics ou privés. 
The Careful Balance of Gender and Sexuality: Rural Gay Men, the Heterosexual Matrix and "Effeminophobia"

\author{
Dr. Alexis ANNES ${ }^{1}$ (corresponding author) \\ South Dakota State University \\ Department of Sociology and Rural Studies \\ SSB 203, Box 504 \\ Brookings, SD 57007 \\ United-States of America \\ Phone: (605)688 4084 \\ Fax : (605)688 6354: \\ alexis.annes@gmail.com \\ Dr. Meredith REDLIN \\ South Dakota State University \\ Department of Sociology and Rural Studies \\ SSB 203, Box 504 \\ Brookings, SD 57007 \\ United-States of America \\ Phone: (605)688 4084 \\ Fax : (605)688 6354: \\ meredith.redlin@sdstate.edu
}

\begin{abstract}
$\underline{\text { Abstract: }}$
Based on life narratives, this article explores rural gay men's subjectivity in France and the United States. After growing up in rural cultures, these gay men tend to adopt similar heterocentered ideas about masculinity. We show that these 'conventional' ideas impact their sense of self as they express feelings of 'effeminophobia'. They differentiate themselves from effeminate gay men and emphasize their similarities with straight men. These ideas are both coercive and disciplinary as they homogenize rural gay men's discourse and masculine identities.
\end{abstract}

Key Words: Rural homosexuality, Gay Men Subjectivity, Heterosexual Matrix, Life Narrative.

\footnotetext{
${ }^{1}$ Present/Permanent Address: Ecole d'Ingénieurs de PURPAN ; 75, voie du TOEC ; BP 57611 ; 31076 TOULOUSE Cedex 3 ; Tél : (33) 561153086 ;Fax : (33) 561153060 ; e-mail: alexis.annes@purpan.fr
} 


\section{Introduction}

On a Friday night in a rural town in the southwest of France, several gay men $^{2}$ met to socialize and relax after a long week. While waiting for the meeting to start, a group of three men in their early 40s were talking about their masculine appearance. They came to the conclusion that they looked as masculine as any straight man, and should they walk down the street, no one would be able to notice they were gay. Being able to be identified by heterosexual traits of masculinity (like, apparently, any other man in the street) was at the center of their preoccupations. Having reached a conclusion about their own level of masculinity, so to speak, the three men began to assess the masculinity of every man in the room. They were more or less sitting in a circle, so one by one, each was submitted to judgment. At first, just the three were engaged, but gradually all the men there joined the discussion. All men in the room were judged "masculine" but one - a young man in his early twenties who was judged significantly effeminate. Other men in the audience concluded that if they had met him on the street, they would have guessed he was gay. The conversation concluded with smiles of satisfaction on all the men who had been judged "masculine." Even as these rural gay men came together to assert and support their gay identities, being masculine and looking straight were clearly appropriate and desirable features. In contrast, being effeminate was clearly disparaged.

This careful, if complex, balancing of sexual and gender identities became an emergent theme in this research examining the life histories of gay men in rural areas of France and the United States. Masculinity and, what is more, 'hegemonic' masculinity, was pivotal to all informants in this study. Whether they claimed it or not, these rural gay men strove to fit a

\footnotetext{
${ }^{2}$ Referring to the participants of this research as "gay men" reflects the way they introduced themselves (they selfidentified as gay men and/or homosexual men in the US and as homo, homosexuals, or gays in France). By using this terminology to refer to them, our aim is to respect their choice and not to impose an identity which they might not have chosen.
} 
conventional model of masculinity in order to pass as "normal." After growing up in rural cultures emphasizing heteronormativity and traditional masculinity (see for example Campbell, Bell and Finney, 2006 in the US context and Saugeres, 2002 in the French context), they tended to adopt a homogeneous hetero-centered discourse about homosexuality by strongly differentiating themselves from effeminate gay men and concurrently emphasizing their similarities with straight men.

This article offers a reflection on the discourse of masculinity for self-identified gay men who grew up in a rural setting in the Southwest of France and the American Midwest. This research asks: What is the meaning of masculinity for gay men who grew up in a rural setting? How is a heteronormative gender identity balanced with self-acceptance of gay sexual identity? What are the subjective effects of this balance in life aspirations and histories for this population? We begin our discussion by placing this work in the context of masculinity studies and briefly establishing the international comparative context in this research. Next, we discuss the use of a grounded theory approach and of life story interviews to better portray informants' subjectivities. We then present our findings in the context of an emergent conceptual typology of heteronormative masculinity, rising from these grounded methodological and analytical processes. We emphasize how rural gay men tend to adopt a hetero-centered discourse when reflecting on their sense of self, and introduce the concept of "effeminophobia" and its relevance in understanding our informants' subjectivities and life narratives. In conclusion, we question the specificity of the identified heterosexual matrix as only affecting gay men who grew up in rural settings. We also advocate for the need of further comparative research, particularly with gay men who grew up in urban settings.

\section{Masculinities}


Masculinity Studies is a developing academic field that arose as a research area in the 1970s due to societal changes and the impact of feminism, which led to the questioning of men's roles (Hearn and Morgan, 1990; Campbell, 2000; Robinson, 2008). Before this, the category of 'male' was treated as the normative reference for all human experience, but 'men' were not seen as an explicit social category and so were invisible in social science research (Connell, 1987;

Kimmel 1987; Edwards, 2006). As masculinity is socially constructed in time and space, different authors argue that it is more relevant to speak about masculinities (Connell 1987; Kimmel 1987; Campbell 2000). However, Connell (1995) argues, by using the concept 'hegemonic masculinity,' each society is characterized by a dominant form of masculinity setting appropriate norms for masculine behaviors and attitudes. Next to this model of dominant masculinity, other forms of masculinity coexist such as subordinated masculinities, counter masculinities, or marginalized masculinities (Connell, 1995), which do not follow cultural ideals and do not benefit from institutional power.

Social environments, Connell, Hearn, and Kimmel (2004) point out, constantly recreate and redefine plural categories such as masculinity in particular and gender in general. Masculinity is constructed in a system of gender expectations and preconceived ideas about what defines a man. These expectations and ideas order and structure individuals' social practices and representations in conjunction with other social structures such as social class, race and ethnicity, age or sexuality. Looking at the 'intersecting' effect of various social structures lies at the heart of the Intersectional Theory agenda developed in the 1990s. Intersectional Theory was developed by feminist scholars in response to critics about the limitation of gender as a single analytical category of analysis (McCall, 2005). This theoretical perspective emphasizes the complexity and the multidimensional character of gender-related issues in opposition to simple and one- 
dimensional approaches to the same issues (Collins, 1990, 2005; Crenshaw, 1991). Thus, Intersectional theory (Collins, 1990, 2005) assesses how gendered people are situated based on race, class, and sexuality, and how this specific location affects and is affected by social interactions and other sources of information. Clearly, it also has an impact on social representations of masculinity.

Recent studies complicate the 'intersectional' effect of these social structures, noting that space also has a decisive role in shaping individuals' sexual and gender identity. In this regard, related to sexual identity, Inness (2004) explains that "the elision of differing subjectivities that constitute gayness is based not only on factors such as race, ethnicity, age, gender, and class, but also geographic location" (p.257). Focusing on gender identity, Andrews (2009) claims that "understanding space is methodologically important because its use and the forms that it takes can provide valuable insights into the practice of identity and illuminate social relationships" (p.168). Therefore, this article recognizes and explores the intersecting role of rural space in shaping rural gay men's subjectivity with other social structures — such as gender and sexuality - in international contexts. Studying the intersection of gender, sexuality and rurality is essential in order to understand the real-life experiences of rural gay men (Lobao, 2006).

Initial studies focusing on rural homosexuality pointed out isolation as a major issue faced by rural gay men (D'Augelli and Hart, 1987; Moses and Hawkins, 1980). A limited number of gay population results in limited possibilities for networking. As suggested by Moses and Hawkins (1980), this limited population also leads to a lower likelihood that individuals will have anything in common apart from their gayness. This homosexual isolation is compounded by the added fear and discomfort about heterosexual people's reaction, pushing rural gay individuals to remain invisible (D'Augelli and Hart, 1987). Research in the 1990s studying the intersection 
between masculinity, homosexuality, and rurality in many ways served to reinforce the emphasis on isolation and rural/urban, hetero/homo dualisms (Bell and Valentine 1995; Fellows, 1996;

Kramer 1995; Loffreda, 2000). For example, Kramer (1995) established the difficulties faced by gay men and lesbians from rural North Dakota in finding a sense of community where they can express their identity freely, without fearing negative reactions from other people. This study underlines the lack of social structures, such as gay bars or bookstores, where they could meet (Kramer, 1995).

However, other studies on rural male homosexuality provide a more complex and nuanced picture of rural life. For instance, studying life experiences of rural gay men in Northern New England, Cody and Welch (1997) identify positive aspects of rural living, despite the continuing issue of isolation. Their respondents note the existence of a quiet, nice and peaceful environment with a slower and less stressful pace of life, as well as the creation of networks of intimacy or a small group of close friends (not necessarily gay) with whom one can socialize and find social support. This simultaneous presence of positive and negative aspects associated with living in a rural setting is reflected in a series of studies in other regions in the United States: Fellows in the American Midwest (1996); Bonfitto in New England (1997); Howard in rural Mississippi (1999); and Forsyth in Massachusetts (1997, 2001). For instance, Fellows (1996) argues that if isolation constituted a central component of the life experiences of his respondents, it was also a saving experience for many of them. He found that "isolation hindered and helped them in coming to recognize and understand their differences," by helping them to avoid "the potentially devastating expectations and ridicule of their other peers" (p.13). If growing up on a farm did not provide information about sexuality in general and homosexuality in particular (due mainly to religious conservatism and sexual prudishness), it facilitated farm boys' escape from 
pressure to conform to standards of masculinity. Living on a farm also helped these boys to "invent themselves according to their inclination and standards" (p.16) and kept them away from constant teasing from other boys ${ }^{3}$.

If some studies have considered masculinity in intersection with gender, sexuality and space (Hockey, Meah, and Robinson, 2007; Howard, 1999), very few of them have considered the effect of this intersection on the construction of Lesbian, Gay, Bisexual and Transsexual (LGBT) individuals' subjectivity. Recently some studies on this intersection have emerged (see for example Gray, 2009 and Kennedy, 2010), however, the relationship between masculine identity, rurality and homosexuality remained poorly documented. This article aims at filling this empirical and theoretical gap by looking at how rural gay men's ideas of masculinity potentially influenced their sense of self and subjectivity, as well as how these ideas are experienced as coercive and disciplinary permeating consciences and practices as suggested by Butler (1990). It explores how rural gay men growing up in the country tend to adopt and integrate a discourse reflecting hetero-centered expectations and conventional ideas about what defines a man, in their own system of representations.

\section{Rural France and United States as Sites of Inquiry}

The choice of the United States and France was made for many reasons. Firstly, both nations constitute postindustrial societies where rural spaces have undergone significant changes and racial, ethnic and sexual diversity exists (Cloke, 2005) but have not been the object of comparative sociological inquiry. Secondly, rural spaces play a significant role in shaping

\footnotetext{
${ }^{3}$ Other studies focusing on rural homosexuality have focused on migration of LGBTQ individuals from the country to the city. If this migration had been conceptualize as unidirectional for a long time, recent studies pointed out the existence of back and forth movements of rural LGBTQ individuals between rural and urban spaces. For more details on this body of work, see Annes and Redlin, 2011.
} 
national identity and imaginary both in France (Ageron and Dora, 1997) and in the US (Bunce, 1994). Lastly, in both countries, rural spaces are sources of rural romanticism promoting heterosexuality (Campbell, Bell and Finney, 2006; Saugeres, 2002) and excluding or marginalizing other orientations (Bell, 2000, 2006). In fact, rural areas in Western societies such as France and the United States, remain highly heteronormative spaces emphasizing nuclear (heterosexual) family lives and stereotypical gender roles and interactions which remain unquestioned (Little, 2003; Little and Panelli, 2007). As recently shown by Campbell, Bell and Finney (2006), they are still closed environments where traditional hetero-masculinity is pervasive and any deviance from it quickly judged. In this specific context, some studies (Cody and Welch, 1997; Fellows, 1996) note that striving to follow traditional forms of masculinity"butch-ing up" or "cowboy-ing up" (Bell, 2006, p.170)—remain common coping strategies for rural gay men to avoid being perceived as effeminate.

However, despite these similarities affecting their cultural construction of rural spaces, these two countries present different cultural and political frameworks on sexuality at the societal level. In the French cultural context, sexuality is perceived as a private matter having no space in the public sphere. Unlike in the United States, where LGBT individuals have identified themselves as a "community" and a movement, in France LGBT individuals have remained abstract individuals in the public sphere. Inherited from the 1789 revolution, the principle of laïcité plays a decisive role in the French Republic and advocates a well-defined separation between the public and the private sphere. French sociologist Eric Fassin (2006) explained that "the separation between the public and the private spheres was [...] intended to prevent the politicization of sexuality" (p.83). French republicanism defines citizens as "abstract individuals" (Johnstone, 2008) whose gender, religion, race or sexuality should not be taken into account. In 
this context, constructing one's identity in terms of sexual difference goes against the founding of French republican ideals (Johnstone, 2008). As explained by Armbrecht (2005) in his provocative article "Can one be gay and French?", "this kind of identity-based politics is known as either communautarism or particularism in France, and is generally seen to be at odds with the universalist ideals upon which the Republic was founded" (p.20). Therefore, in France, acceptance of differences is believed to lead to the fragmentation of social reality and the breakdown of the social order (Martel, 1999). Consequently, capitalizing on any personal difference in general, and on sexual difference in particular, leads to a threat to the unity of the French Republic.

Following this argument, LGBT individuals should not privilege their sexuality as a source of identity over the universal concept of "Frenchness". These "universalist republican ideals" have been criticized by scholars working on minority issues in the French context for promoting a model only reflecting White, male, bourgeois, and heterosexual norms (Blidon, 2010; Cervulle and Rees-Roberts, 2010; Tin, 2008). For example, Cervulle and Rees-Roberts (2010) argue that this ideal erases forms of belonging (sexual, religious, ethnic or racial belonging) other than citizenship and mixes national union, Republic uniqueness and uniformity of identity. Hence, it flattens out diversity and, in the context of their studies, denies the reality of French multicultural foundations.

This model contrasts with the American community-based model of social and political collectivities and diverse individualisms. In the United States, individual difference constitutes a principal source of social organization, and identity itself is a political and public force (Calhoun, 1994). Rather than the French republican "universal individual", U.S. culture forwards the specificity of identity, establishing links between personal traits, beliefs and/or orientations and 
the strategic collectivities which emerge along these elements of personal identity (e.g., the civil rights movements in the 1950s, the feminist movement in the 1960s, and the gay and lesbian movement in the 1970s.). American political and cultural movements reflect the diverse and very private nature of identity (e.g., race, ethnicity, sexual orientation, age) which is rejected in the French cultural framework. However, it is important to note that acceptance of difference, while constituting a principal source of social organization within the United States, does not mean that all identities are therefore equal or equally powerful (See Lipsitz, G. How White People Profit from Identity Politics, 2006). For our purposes here, it is important to note that the formation of gay subjectivities and communities occurs within constraints on gay subjects. Recent studies note how, in order to build a sense a self, rural gay subjects need to negotiate the conservativeness of the social landscape in which they live (see for example, Gray, M. Out in the Country: Youth, Media, and Queer Visibility in Rural America, 2009).

Therefore, comparison of the presence of American and French similarities (i.e., heteronormative rural spaces undergoing similar changes) and differences (i.e., conceptualization of sexuality and sexual identity at the societal and political level) uniquely informs the process by which respondents establish subjective gay identity in conjunction with culturally specific masculine norms.

\section{Methods: Reaching Participant Subjectivity}

This article is part of a larger project focusing on understanding the intersecting role of gender, sexuality, and space in shaping rural gay men's identity. We employ a grounded theory approach as one of the major goals of this study was to contribute to the development of theoretical and conceptual knowledge in the field of masculinity in general and rural masculine 
homosexualities in particular. Grounded theory is a methodology where the focus-is on generating a theory from data (Glaser and Strauss, 2006) rather than on using existing theory to expand social understanding. Grounded theory appears as a set of flexible guidelines which aim to generate new concepts and frameworks which both emerge from and closely reflect research data (Charmaz, 2006). The lack of existing sociological work regarding rural masculine homosexualities spoke to the need for the theory-building and deep research inherent in this methodological approach.

Additionally because masculinity, homosexuality, and rurality are socially constructed, exist in people's consciousness, and are expressed through everyday practices, it is methodologically relevant to study them from the subjective point of view of those who live within them (Sasson-Levy, 2002). Thus, this research project was informed by qualitative research methodology to allow interpretations of participants' discourse, "to understand the meaning of respondents' experiences and life words" (Warren, 2002, p.84). In this way, men's sexual and gendered subjectivities can be interrogated in a nuanced manner.

To gather data, life story interviews were used. A life story interview is "the story a person chooses to tell about the life he or she had lived, told as completely as possible, what the person remembers of it and what he or she wants other to know of it, usually as a result of a guided interview by another" (Atkinson, 2002). Life story interviews give "rich evidence about impersonal and collective processes as well as about subjectivity" (Connell, 2005, p.89). In other words, the relevance of life histories rests on the fact they give a rich documentation of personal experience and subjectivity as well as an in-depth understanding of social, cultural, and historical structures shaping this personal experience over the life course. 


\section{Participants}

The informants were 30 self-identified rural gay men-15 of them grew up in the Northern American Great Plains, and 15 of them in the Southwest of France whether in rural towns, in villages, or on a farm ${ }^{4}$. All American participants spent, at least, their entire childhood and adolescence on a farm or in a rural town with less than 5,000 inhabitants. At the time of the interview, only one still lived on a farm. Among the seven participants who lived in a town with between 5,000 and 25,000 inhabitants, four were students who were planning on moving to urban places in the coming years. All French informants spent, at least, their entire childhood and adolescence in places with less than 2,500 inhabitants. At the time of the interview, among the five informants who lived in a city with more than 25,000 inhabitants, two were students who were unsure about where they would end up living in the coming years.

The men, ranged from 19 to 62 years of age, and were mostly white and middle class. Distribution across age and social class was similar for American and French informants. Among the French participants, one was a second-generation immigrant from Algeria, all the others were Caucasian. Among the American participants, all were Caucasian except one who was a secondgeneration immigrant from China.

Regarding occupation, among the American participants, four were full-time college students. Eight participants were from the middle class and were working as a nurse, a research assistant, a physical therapist, a restaurant manager, a real estate agent, and a teacher. One participant was retired. Two participants were from the working class. One was a truck driver and had cattle, the other was a carpenter. Among the French participants, three were full-time students. Eight were from the middle class and most were working as employees of public and

\footnotetext{
${ }^{4}$ The major goal of this study is to assess how, growing up in the country, gay men built their sense of self and subjectivity. Therefore, at time of their interview, some informants did not live necessarily in the country anymore. Nonetheless they spent their entire childhood and adolescence in a rural environment.
} 
service companies. One was an artist, and one was an extension agricultural technician. Among the rest of the participants, one was retired, one was a farmer, and two were blue collar workers.

All were involved, at least occasionally, in LGBT organizations located in rural towns of the American Midwest and in the Southwest of France and bringing together people from surrounding small towns, villages and farms. Initial participants were reached by using these existing networks of LGBT organizations. As a result of the research design, the research population does not contain men who grew up in rural areas and (1) who have sex with other men but do not identify themselves as gay or (2) who identify themselves as gay but are not involved in existing regional LGBT organizations. This initial sampling was then expanded by techniques of theoretical sampling - interviewees are selected based on analytical findings so far (Corbin and Strauss, 2007), and snowball sampling - interviewees are asked to mention other potential participants based on criteria given by the researchers (Noy, 2008). Data were collected from June 2007 to February 2008 and collected through semi-structured interviews by asking participants to provide an account of their life story.

It is important to note that there is a wide variety of rural contexts in which LGBT individuals live and that we are not trying to create a universal and uniform experience of the rural. We recognize that non-heterosexual experiences are plural and sometimes contradictory. Therefore, this study emphasizes the situated knowledge (Haraway, 1988) of self-identified gay men who participated in this study and, consequently, only reports on their perspectives and representations.

\section{Masculine Typologies in Rural Gay Experience}


When trying to make sense out of their sexuality, both American and French informants tend to adopt a similar discourse on what it means to them to be a gay man, resulting in what Connell described as "very straight gay men" (Connell, 1992). They tend to distance themselves strongly from effeminate gay men while they emphasize their similarities with straight men. Additionally, the discourse they adopt appears significantly hetero-centered. In this discourse, we observed the emergence of four processes of presenting the self which balances sexual and gender identities. These four processes are presented below as four typologies: (1) I am queer, yes... but I am not a queen, (2) I am queer, yes...but I did not choose it, (3) I am queer, yes... but I am still a man, and (4) I am queer, yes... but I want a lifelong partner and kids.

\section{I am queer, yes...but I am not a queen}

Distancing oneself from effeminate gay men was powerfully expressed among French men who made a very strong claim asserting their difference with "les folles" (queens). For French informants, "les folles" are overtly effeminate gay men who disturb "normality" and give a negative image of homosexuality. Michel $^{5}$ — a closeted gay man in his mid-50s who still works the land with his parents — gave the following definition of a "queen:"

It's someone really "maniérê" (mannered), I don't know how to put it...someone really mannered, yelling, just acting crazy! Personally, I don't do it. I know some guys who are really effeminate but personally I haven't reached that stage. I am manly and I would not like to be effeminate. If a man is effeminate I don't flirt with him, I don't like him.

Michel's perception of a queen reflects the general perception of other French

informants. For them, "une folle" (a queen) is a gay man whose behavior lacks of simplicity and who is ceremonious, precious and, at times, dramatic. Moreover, "les folles" (queens) are eccentric individuals whose tone of voice can be, at times, high pitch, who are not manly, who

\footnotetext{
${ }^{5}$ For this study, the names of all the participants as well as the places where they grew up and currently live are confidential, and all participant names are false.
} 
do not follow traditional gender expectations, and therefore who disturb "normal life." Also, as Michel describes, most of the interviewees claimed that they were not attracted to "queens" as they were too woman-like. They often explained that they were gay because they were physically and emotionally attracted to men, which is to be understood as attracted to masculine men.

When, at a young age, they started feeling attracted to other men but were not able to explain their feelings, gay men who did not know much about homosexuality experienced the dominant discourse as portraying gay men as effeminate. A significant number of them interacted with effeminate (assumed gay) men during high school. Observing how these individuals were treated by others, how they were ostracized, seems to have encouraged my interviewees to distance themselves from effeminate men.

Jean-Pierre — a gay man in his late 30s—remembered one of these students in high school who was the object of others' (mainly male students) derogatory comments:

At this time, I did not accept who I was, and, because in my class there was another guy who was gay... He was very effeminate, so I think my difficulty to come to terms with my sexuality was also coming from the rejection of that, from the feminine appearance of this guy, of this individual.

Guillaume, a younger man in his early 20 s, also mentioned such a student: "I remember this student, because he was effeminate, because he was gay, it was not accepted by others, so... obviously it did not encourage me to say I was gay. He was called a fag, a girl, all the usual insults that we hear about homosexuals."

The two male students that Jean-Pierre and Guillaume are referring to here were ostracized and constituted as appropriate targets for others' criticism because they departed from traditional gender expectations. The following quotes from Yannick, a man in his late-20s, who was considered as being effeminate by his peers when he was a student, shed on what it means to 
be "effeminate" in the French context and to depart from traditional gender expectations. When he was asked how people where making him feel different, he explained:

The way they behave with you. . . In fact, I was very shy, I don't know if it comes from that or not, but I was really really shy, and, you know, people keep on....and also...also it was visible. . . because. . . I was. . . I was "maniéré" (mannered), and. . people make you feel different by telling you not to move like this or not to do that. I quit soccer to play the piano. Soccer is something very important, and when you are a boy, you play soccer. I was not playing soccer anymore, and people make you feel that you are outside the norms.

Again, being "maniérê" (mannered), which is usually associated with more a feminine manner, refers to a ceremonious, precious and even dramatic behavior lacking of simplicity is pointed out as an inappropriate behavior for young men. Not playing soccer, a sport perceived as typically masculine in France, but having an interest in a more artistic activity, playing the piano in that case, also reflects a departure from traditional gender norms. Therefore, for the French informants, "effeminate" students were disturbing presumed traditional expectations linking masculinity and biology. In their eyes, a man (straight or gay) has to follow traditional masculine expectations; any individual who disturbs that order can be ostracized by peers and the source of derision. Jean-Pierre and Guillaume, mentioned previously, did not identify themselves with these two students because they perceived themselves as masculine, even though at this time they started considering the possibility of being gay. For them, being a man and being effeminate meant being ostracized and cast out from the "group." When we asked Thierry, a student who recently came out to his family, if he had been involved in a relationship with an effeminate gay man, he answered:

Yes, it already happened to me... I don't know... I don't know if we can speak about degrees because... I don't know... but to the point to bring someone effeminate home... if I am really in love, I think it would bother me, but I would do it. It would bother me because it would be someone who would be stigmatized because of his 
sexuality and people would see him only through that. I think it's mainly because of that [that it would bother me to bring him home].

Clearly here, being effeminate means being identified and recognized by others as being gay, and being eventually rejected because of that. It also means being only seen through one's sexuality and not through other features. Thus, being an effeminate gay man signifies bringing one's sexuality to the public sphere and not feeling guilty or ashamed of it - feelings that one could (or should?) experience given the expected link between biology and gendered behaviors as we noted above. Following this train of thought, effeminate gay men were also blamed by French informants for being eccentric and, once again, for bringing their sexual orientation to the forefront. Guillaume explained:

I really don't like eccentricity. I am gay, but I don't see myself shouting it from the rooftops. If people asked me if I am or not, I would say yes, but I won't shout it everywhere because I feel that it is something private and it is not because you are straight that you had sex with a girl.

Here, eccentricity ${ }^{6}$ — to be understood as being effeminate — signifies that one is "proud" of being gay and wants to claim it in the public sphere. For Guillaume, sexuality should be kept private and no pride should arise from anyone's sexual orientation. He wants to be treated "normally" like anyone else, that is, anyone else who is heterosexual.

Not finding effeminate gays attractive is not specific to French interviewees. The majority of American informants also expressed their reluctance to get involved in a relationship with an effeminate gay man. They tend to be more attracted to masculine men as John —a man in his early 50s-explained:

I was entertained by the drag queens, but I had no inclination in dressing up like a drag, and I was not attracted to the drag queens or the very effeminate men in the bars. I wanted a man, I wanted somebody with hair, and blisters, and dirty clothes... and even smelly.

\footnotetext{
${ }^{6}$ In his context and in the French culture, "eccentricity," as well as "flamboyance" and "mannerism" are features associated with effeminate gay men.
} 
This non-attraction to effeminate gay men was expressed by gay men from different generations. When asked what type of men he was attracted to, Jordan — a young man in his mid20s and currently in a relationship — used the example of a character from Another Gay Movie:

You know the guy who has the mom who is also the mom in Queer as Folk. That guy who has all these little outfits, that kind of guy, not to be stereotypical or anything... but... I don't know. I am not attracted to a guy who would be wearing a feather boa or wears a big triangle shirt or who is extremely, extremely effeminate. I like guys who are guys, who are masculine. If I wanted extremely feminine or whatever I would date women.

Jordan expresses here the same type of ideas expressed earlier by French gay men. He is not attracted to effeminate men because he is not attracted to women-for him an effeminate man does not behave like a man, but a woman. Moving away from these norms, one becomes a deviant. Nathan, a gay man in his mid- 30s who considers himself a jock, stated the same type of opinion about effeminate gay men, but also tried to explain where it came from:

I am not attracted to the real feminine like the ones who wear the bright boas, and, you know, if you put them in a dress, they would fit right in. I want more... I am attracted more to a "guy," not a feminine guy. There are some guys attracted to feminine guys, I am not. Maybe it goes back to growing up in a rural area on a farm, and you know, if you are a guy, you act like a guy. You don't go around walking with a purse.

Nathan grew up on a farm near a small town in the Upper Midwest. For him, growing up in such an environment might explain his attraction to masculine men and also his own very masculine behavior. His comment echoes the studies about the heteronormative nature of rural cultures in Western societies mentioned earlier (Campbell, Bell and Finney, 2006; Little, 2003; Little and Panelli, 2007). These studies emphasize the persistence of stereotypical gender roles in general and of traditional hetero-masculinity in particular, as well as its impact on rural individuals' behaviors and perceptions of themselves. In the context in which Nathan grew up, a family farm in a rural region, men ought to behave like they are expected to ("if you are a guy, 
you act like a guy"), and they are not allowed to express behaviors which could be associated with a counter-hegemonic type of masculinity ("you don't go around walking with a purse"). It is interesting to note that Nathan knows about some men who are, contrary to him, attracted to feminine men. Here he demonstrates a broader knowledge of a sexual continuum in gay culture, but clearly, he does not value it.

The fact that masculine men are perceived as "normal" whereas effeminate men are perceived as "abnormal" is also stressed in Tyler's comment when asked to describe his boyfriend. Tyler and Sam (who were interviewed one week apart from each other) had been involved in a relationship for two years at the time of the interviews:

He is... very normal. He is not effeminate at all. He wears T-shirts and shorts like any college town guy, some of his mannerisms and speech patterns are sometimes a little bit gay, but his interests are similar to mine. We are both interested in art, music, language, culture, and not so much at...well he would do better than me at watching a football game.

Tyler considers Sam a "very normal" guy who looks like the typical college student, despite some mannerisms and speech patterns. Even if Sam enjoys "art, music, language and culture," interests not necessarily associated with traditional rural masculinity (Campbell, Bell and Finney, 2006), he is also able to enjoy a football game. This double interest could certainly be interpreted as the possibility for some "roaming" beyond the expectations of normative (rural) masculinity. However, mentioning that Sam is able to watch a football game at the end of the quote stresses his acquaintance for traditional masculine interests and behaviors, despite some non-traditional ones. Therefore, Sam keeps on fitting the image of what constitutes a "normal" guy, which is a heterosexual man who wears T-shirts, shorts, and who enjoys watching football games. When Tyler was asked if he would be able to date an effeminate man, he explained: 
My last boyfriend was fairly effeminate. He does not look effeminate but sometimes his manners were just... but there have been guys who were interested in dating me, and it was unattractive to me that they were so effeminate. Just to me, it is almost like "if I wanted to be with a woman, I would be", but I am not, so I am not overly interested in overly effeminate characteristics.

Once more, Tyler's comments emphasize the integration of stereotypical ideas conflating gender and sexual identity. According to him, feminine traits and behaviors are the prerogative of women. However, his comment also brings more complication to his relationship to effeminate gay men and might suggest a contradiction between his discourse, rejecting effeminate gay men who he sees as being unattractive, and the fact he actually dated one, albeit an effeminate man who did not "look" effeminate. This qualification suggests however only a slight degree of acceptance of effeminacy (in practice) and a continued rejection of it (in discourse).

\section{I am queer, yes...but I did not choose it}

Both French and American informants tend to make a point in distancing themselves from effeminate gay men, who are perceived as disturbing 'normality' in a world where men, gay or straight, ought to be masculine. When reflecting on their same sex desires and attractions, they tend to sustain an essentialist narrative, reflecting on the general resurgence of this discourse in Western societies when it comes sexual and gender identities, as recently pointed out by Lancaster (2006).

Both American and French interviewees define "being a gay man" as being attracted mentally, physically, emotionally, and sexually to other men. All of them explain their same-sex desires and attraction as something they did not choose, as something biological that they had to accept, and therefore, something that there was no point in questioning. Trevor, an American 
college student in his early 20 s, had to go through a long process before accepting his same-sex desires and attractions. When he was still in high school, he was literally dreaming about becoming straight as he could not imagine leading a "normal" life as a gay man. For him, leading a "normal" life was, in his own words, "getting married and having kids." In contrast, Christopher was an American who recently graduated from college and who had been "out" since high school. He spoke of what his grandmother thought about him being gay. The two of them had a very close relationship; he said: "I have lived as an openly gay man since high school, I think she has understood that it is very natural." For Christopher, his sexuality is undoubtedly something natural, which should not be questioned. At the time of the interview, he had been involved in a relationship for more than two years. When we asked him about his current thoughts about homosexuality, he replied:

I really had to go through the whole process of "I am gay", I also had to go through the process of "I did not choose this." I had to go through that, too. I had to tell myself that it is not a choice, it is set, and you are born with it. Now I have a greater understanding of what it is, not just because I have accepted it myself, but because I am able to meet other people, and their experiences and their thoughts.

This quotation reflects the view that homosexuality is not something chosen, it appears more as an inherent individual characteristic which requires time to accept and to come to term with. In fact, as Christopher said, "it is not a choice," but "it is set, and you are born with it." Like Christopher, both American and French informants perceive their homosexuality is a biological characteristic which has been "in them" since their birth. Reflecting on his sexuality, Jean-Pierre - a French gay man who recently moved back to the country with his long term partner-explained:

My homosexuality, for many years, I had been hiding it, I couldn't come to terms with it. Then in 1992, I had a serious accident, I was at the hospital, it was quite serious, I almost lost one of my legs. At the hospital, I did a lot of thinking, I told myself that I should do 
something, I should come to terms with my homosexuality. So it is when I spilled the beans.

For many years, Jean-Pierre felt that his homosexuality existed "inside him" but was repressed. While he had not come to terms with it, a particular life event made him question his life. He then decided to accept it and to cope with it. Michael—a French man in his late 20sexpressed the same ideas when he described the time when he decided to leave his family household to lead his own life:

My mom was telling me not to be a waiter, that it was a job only for homos, that I was going to meet [the] wrong people. I did it nevertheless. I became independent, I had an apartment, I had friends... I started to understand I was gay, not straight, I started to date guys, to lead my own life, to put my homosexuality into practice.

Again, this comment underlines the idea that homosexuality is a characteristic that had been existing within one individual for a long time, but that had been "put aside" and ignored for many years. After accepting one's homosexuality, it is then time to put this inherent characteristic that had been shut off "into practice". Conceptualizing one's sexuality as biologically determined as something one's cannot change, could be interpreted as a means to legitimate it and, consequently, place it beyond question. As argued by Halperin (2007), this type of discourse, insisting on the biological and unchanging nature of homosexuality, exists among a majority of gay men, not necessarily rural, and reflects a need to be accepted by, and integrated in, the community.

Both American and French participants tended to view their sexuality as an inherent characteristic they did not choose and as something which they simply had to accept without further question. However, while both American and French gay men view their sexuality as natural and independent of their own will, some differences exist in their broader definition of 
sexuality. French interviewees tend to view human sexuality as divided in two well defined categories (heterosexuality and homosexuality). Contrary to this dichotomous construction, American interviewees tend to handle human sexuality as a spectrum or a continuum. A vast majority of them mentioned one of these two terms when giving their opinion about sexuality. To the American in this study, human sexuality cannot be reduced to two exclusive categories of heterosexuality and homosexuality. Trevor explained: "For me, at the beginning, I thought it was gay or not, gay or straight, and you learn that it is a spectrum, it is not even three categories, gay, straight, and bisexual. It is a continuum and you fall on that line somewhere." At one point during his interview, David, a 60-year old American gay man in charge of a LGBT origination in the Midwest, explained why he changed his view, and became more accepting, of effeminate gay men:

Well, I became friends and learned a lot more about it. I guess I just understood that everyone needs to be who they are, and if there is somebody who is naturally effeminate...how we try to push everybody into narrow boxes and stereotypes...they don't fit, they hurt, they hurt people. Reality is more like a spectrum than these categories... So becoming friends and knowing people, helped me to change.

For both Trevor and David, if one wants to approach human sexuality in a way that reflects reality, one should see it as a continuum not a set of two or three categories (straight, gay, and bisexual). As noted previously, this idea of the existence of a "sexual spectrum" only emerged from interviews with American informants. This might be explained by the cultural impact that the work of Alfred Kinsey had on US society. ${ }^{7}$

I am queer, yes...but I am still a man

\footnotetext{
${ }^{7}$ For more information about the cultural impact of Kinsey reports in American society, see Reumann, M.. ( 2006). American Sexual Character: Sex, Gender, and National Identity in the Kinsey Reports. Berkeley: University of California.
} 
American and French informants both considered their sexual orientation as natural, not a choice. In addition, all interviewees did not demonstrate any hesitation when asked to define homosexuality and to express what it meant to them to be a gay man. However, defining masculinity and what it meant to them to be a man was more challenging. Usually, if the issue had not been already addressed during the interview, we asked informants to define masculinity and what it meant to them to be a man. Following are two quotes representative of the content and the form of answers given by French informants. First, Thierry, the student who recently came out to his family, expressed the belief that all men are masculine.

Can you define masculinity?

Masculinity? No, not really. No I don't know.

What is a masculine man to you, then?

Oh, yes. Well, no... It's hard to imagine, hard to define. In fact, it seems to me that all men are masculine.

Second, Jean-Pierre, the gay man in his late 30 s who recently decided to move back to the country with his long-term partner, also experienced some difficulties to express and reflect on his definition and perception of masculinity:

Can you define masculinity?

Well... no. Not really... it's a man. It's a man, it's somebody masculine. It's difficult for me... it's not necessarily the big guy with a moustache... it's... I think it is being who you are, to be masculine... no, I can't define it.

What does "being a man" mean to you then?

To be a man...it's hard to define...we are all men. It's not because one is gay that one is not a man, to the contrary. Being a man means having a normal life.

Could you define what a masculine man is?

It's someone like you, someone who can disappear in the crowd. It's my partner. It's someone common.

Both excerpts from Thierry's and Jean-Pierre's interviews exemplify the difficulties that French informants experienced when trying to define and reflect on the meaning of masculinity. 
Their inability to reflect on their masculinity reveals that masculinity is not perceived as a subject of inquiry for them in particular, nor for the general population. It seems that their struggles to answer these questions also stem from their feeling that there is no point in asking such things. For them, masculinity seems to be an "essence" which should not be interrogated. For the majority of French informants, being a man and being masculine are the same, and because of that, all men are masculine. In fact being masculine is "being who you are," again clearly linking biology with an obligation to perform heteronormative masculinity. Also, being a man and being masculine means to blend in with the crowd, to look "normal" (which means following typical gender expectations and not challenging them).

The construction of masculinity as "naturally" associated with being a man was also clearly expressed by Michael, a French informant, when we asked him if he considered himself a masculine man: “[Yes]. Yes, I am a man. I am a man so I am masculine.” Here Michael clearly equates being a man with being masculine. There is no point in questioning his masculinity; in fact being a man predestined him to be masculine. Later on in the interview, he expressed his satisfaction at not being effeminate. He mentioned that growing up in the country, in contrast to growing up in a city, allowed him not to become effeminate. Not without satisfaction, he said: "I am glad I did not become effeminate because I think that one has to remain natural. It's not because you are gay that one has to start looking like a girl. Personally, I am proud to be a man." Again, Michael expressed statements repeated by French participants: masculinity is a natural feature characterizing men.

However, if, at first, it appears that French informants claim that masculinity is an essence ("being masculine is being who you are"), some inconsistencies stem from their discourse. In fact, by also stressing ideas such as "being masculine means to blend in the crowd, 
to look "normal," they ignore the paradox between masculinity as something one "is" and the regulation and scrutiny which are involved in their "effortless" (so they say) manifestation of something which is "innate." When Michael claims "yes, I am a man, I am man so I am masculine" as well as the fact that not growing up in a city allowed him not become effeminate, he actually underlines the possibility of disassociating one's biological identity ("being a male") and one's gender identity ("being effeminate"). However, according to his comments, it seems that he believes this is not the result of individual agency but more the consequence of the environment. Therefore, his comment only substitutes biological determinism for environment determinism.

American informants' definition of masculinity and accounts of what it means to them to be a man are notably more complex. If French informants tend to view gender as two exclusive categories - masculine and feminine — attached to the two biological sexes - male and femaleAmerican gay men tend to see gender on a continuum. David, a gay man in his 60s, who is in charge of a LGBT group in the Midwest explained that:

I have been told that there is a spectrum that goes from masculine to feminine and I am somewhere in the middle. There are gay men who are in professional sports; they are as tough as any straight athletes would be, and then, on the other side, you will find queens, drag-queens, and extremely effeminate gay men.

As they did when they spoke about human sexuality, most American gay men mentioned the existence of a gender continuum going from masculine to feminine. For them, each individual — male or female, heterosexual or homosexual—falls on one part of the continuum. When we asked Tyler (a gay man in his early 30s who runs his family restaurant) to define masculinity, he told me:

I don't have as much as a clear definition as other people, I think. There are no lines in the spectrum of masculinity and femininity. It's a sort of a spectrum, I think. I don't 
know, I think I am three quarters of the way on the masculine side of the spectrum and one quarter on the feminine side of it.

As did Tyler, most of the gay men interviewed recognized that they are not " $100 \%$ masculine," but that they fall somewhere in between in the spectrum. Thus, they tended to complicate the essentialist definition of masculinity held by French gay men. However, they still recognized the importance of being masculine in order to feel more "normal" and to be more accepted. For example, Larry, an American gay men in his mid-20s, was asked to define masculinity, he answered:

Within the gay community, there are a lot of people who strive for masculinity. I don't really know why; it's not something I pay attention to so much. I guess they do that because they want to be more normal, to fit in. I don't really know, but I would say it is because of that.

Larry's comment still outlines the existence of a dominant discourse portraying "normal" men as masculine (and as an extension, "normal" women as feminine). However, personally, he does not endeavor to attain the label 'manly' and does not pay too much attention to this discourse. Then, when asked what masculinity was to him and if he considered himself masculine, he said:

Masculinity is probably a look, maybe not so much a character trait, but an appearance. Probably tall, dark... probably dressing like the Marlboro man. I don't really consider myself masculine. No, not really. I am kind of in-between. I don't know why, I don't necessarily analyze myself but, I guess it is probably just a ranking scale, and you get put in that scale by other people.

\section{Where do other people put you on that scale?}

It depends on whom. Like if it is people at the university who are not surrounded by a lot of gay people, they [would] probably say that I am more flamboyant than [would] my gay friends that I hang out with who say I am more masculine. 
First, Larry's comment suggests that masculinity is not necessarily an "essence" (like French informants did), but that it is externally signified by appearance. Second, he echoes other American participants in recognizing that a continuum exists. However, American interviewees do not find consensus on how one is placed on that continuum. Their discussion suggests that, for American informants, the link between biology and gendered behaviors is more nuanced than that of French informants. Notable however is that their preference for heteronormative appearance and behaviors remains.

\section{I am queer, yes... but I want a lifelong partner and kids}

This presentation of self, emphasizing masculine traits, the essentialist nature of sexuality and difference with effeminate gay men we observed among our informants, seems also to be translated into practices. If the polarity between masculine and effeminate appearance constitutes an important divide in the history of homosexuality in Western society, same thing happens with the divide between exclusive and long-term relationships and relationships allowing sexual encounters with multiple partners (Eribon, 1999). Being in a long-term and monogamous relationship is perceived by its advocates as what constitutes a "normal" life. When they think about their future, the vast majority of the informants (more than three quarters of the French and American informants) wish to find a lifelong partner with whom they can have a stable relationship, and maybe children.

Among the 15 American informants, four of them were involved in a relationship. Among these four, two of them were living with their partner and two others had partners but were not living together yet. Those with current partners pictured the relationship as long-term, and also expressed a wish to have children. Eleven of the American men were not involved in a 
long-term relationship at the time of the interview. Four of them were college students and less than 25 years old. Yet, when asked how they pictured their future, all of these young men mentioned having a life-long partner and children. Three interviewees were between 30 and 45; all of them were looking for a partner and were hoping to have children. One of them explained:

I do wish I can find somebody to spend my life with, to share my life with. I would love to have kids. I wish I can find that person and stay on my farm. I have a brand new house, I have my livestock, I have my life. If I meet somebody and I really truly love him, and he couldn't live on the farm, or say if I meet somebody from a big city and if I truly love this person, but if he can't come because he has a job, I will leave everything I have. My wish for me is to find somebody to share my life here, but I also have to respect his desires.

Four of them were over 50 and most of these informants presumed that their age precluded the possibility of a long-term relationship although their reasoning differed. One was recently divorced from a long-term heterosexual relationship and now assumed he was too old too old to get involved in a new long-term relationship with a man. Another had never been involved in a long-term relationship as he had experienced serious difficulties in accepting his sexuality. The last two men were no longer looking for long-term relationships, although for a long time they had done so because they thought he was the right thing to do. After several failed relationships, they stopped looking as they realized that they might not be suited to live in a longterm relationship. Both viewed their lives as well-established and felt it would be hard for them to readjust for a partner. Although these older men were no longer actively seeking long-term partner, three of them maintain relationships through political involvement. strongly involved in local and regional LGBT rights organizations, and their future goals emphasized continued advocacy for LGBT rights. 
While age and rural residency complicated American participants' aspirations and/or success in finding a lifelong partner and establishing a family, they all continued to advocate those roles as appropriate and integral to a "normal" life.

Among the 15 French informants, nine of them were involved in a long-term relationship. Among these six informants not involved in a long term relationship, only two said that they were not looking for a long-term partner anymore. One of them, Michel, is in his mid-50s, lives on the farm where he was born and still works the land with his parents. He is not out and has no intention to come out. For him, homosexuality is a type of sexuality to experience secretly in cruising areas or gay clubs. Alain, in his early 40s, looked for a long-term relationship for several years and, being unable to find one, gave up. He noted that he realized that being in a long-term relationship was not for him, not necessarily because of his sexuality, but because he realized that one can be happy and have a fulfilling life without being in a stable relationship with children. All the other informants - nine of them - were involved in a relationship at the time of the interview. They hoped to be able to spend a good share, not to say their entire life, with their partner. Most of them would like to have children but were disappointed by the fact that France has not yet legalized adoption for same-sex couples. All of them were hoping for changes in the future ${ }^{8}$.

According to Rubin (1984) "modern Western societies appraise sex acts according to a hierarchical system of sexual value" (p.151). In this hierarchal value system, marital, exclusive and reproductive heterosexual relationships occupy the top part of the pyramid, whereas unmarried, promiscuous, non-reproductive homosexual ones stand at the bottom. Further, she explained that "stable, long-term lesbian and gay male couples are verging on respectability, but

\footnotetext{
${ }^{8}$ In the coming presidential election, gay marriage as well as authorizing gay couples to adopt children is going to be a major focus during the campaign. Candidates from the left parties (Parti Socialiste, Les Verts) claiming that, should they win the election, they would legislate in that direction.
} 
bar dykes and promiscuous gay men are hovering just above the groups at the very bottom of the pyramid" (p.151). Therefore, even if homosexuality still stands on the lower part of the pyramid, homosexual monogamous couples are moving up on the scale. Wanting to be involved in longrelationships and emphasizing the conformity between their sex and their gender identity could be interpreted as a way to "move up the scale of values" and to gain legitimacy next to the community.

\section{Masculinity, Normality, and the Heterosexual Matrix}

The typologies presented above show that both American and French informants distance themselves, albeit to varying degrees, from effeminate gay men. These typologies also reflect both acceptance of their gay identity (at least to this point in the men's lives) and rejection of effeminate gay men. Clearly, sexuality and masculinity are both important in the lives of gay men we interviewed.

However, it also appears from this analysis that masculinity is more problematic than sexuality. Gay men interviewed stress the essentialist nature of sexuality. They all consider that they did not choose to be gay — it was in their genes, so why question it any longer? As a matter of fact, all the gay men interviewed, but one, have come to terms with their same-sex desires and attractions. The only one who did not is an American college student in his late 20s who grew up in a very conservative religious family. He still, at times, sees himself as an abomination as it reflects the discourse he has heard since his childhood regarding homosexuality. However, like all the other informants—regardless of their nationality, age ${ }^{9}$, or religion—-he claims that his

\footnotetext{
${ }^{9}$ Age is clearly significant in analysis of gay experiences in general and of the coming-out process in particular (see for example Floyd and Bakeman, 2006). However, in our study, there remains a continuity across ages in the perception of accepting sexuality with a corresponding obligation to perform heteronormative masculinity. Therefore, age is not a primary factor in this study.
} 
sexuality was not a choice. For them, their sexuality is not problematic, or at least not subject to question.

If sexuality is not problematic, how one displays gender continues to be the source of much discussion. All informants had a negative view of effeminate gay men for several reasons. First, according to participants, effeminate gay men do not challenge the dominant societal ideology conflating homosexuality and effeminacy, and consequently contribute to the reinforcement of this discourse. All informants expressed concerns about representations of homosexual men in popular culture as effeminate, representations in which they did not recognize themselves. Thus, all of them appreciated the movie Brokeback Mountain for portraying gay men as "manly". For all participants, both French and American, gay men portrayed in the movie "look like any other guy from the area" (as stated by one informant) and "do things that any other men in the country would do" (as stated by another informant). It is interesting to note that one participant did not like the movie, but, not for portraying masculine gay men, but for stressing to much the sexual component of the relationship of the two protagonists. According to this informant, the movie was then spreading the idea that gay men are "lecherous" individuals, when it should have emphasized the possibility for this couple to live a long-term monogamous relationship. This point echoes Rubin's (1984) argument that, inherited from the Christian tradition, in Western societies sex is viewed as inherently sinful and can only "be redeemed if performed within marriage (...)" (p.150). The informant's perspective illustrates the importance he attaches to the fact that homosexuality can be performed in the same way as heterosexuality is in order to gain legitimacy and acceptance.

Second, informants blame effeminate gay men for disseminating negative images of homosexuality because of their emphasis on superficial matters such as clothes, fashion, and 
casual sexual encounters. In their stereotypical view of effeminate gay men, they link effeminacy and flamboyance performed through the use of external, feminine signifiers. By doing that, they believe effeminate gays bring their sexuality to the public sphere. In fact, by being flamboyant, they are immediately categorized as homosexual and others view them only through this feature.

Last, French informants also disapprove of effeminate gays for disturbing the presumed link between biology and expected gender behaviors. According to French informants' representations, men—regardless of their sexual orientation—ought to be masculine, and women — regardless of their sexual orientation—ought to be feminine. As they are men, effeminate gays are perceived as abnormal and deviant. Although French informants believe that one cannot choose to be gay, they also believe one is socially obliged to perform as masculine or feminine, as indicated by biology. For them any one challenging the dichotomy of masculinity and femininity challenges the natural order and its cohesiveness.

During interviews, both in France and in the US, these negative feelings about effeminate gay men arose repeatedly. Indeed, it appeared first that informants were expressing internalized homophobia. Herek (2004) argues that internalized homophobia "involves negative feelings about one's own homosexuality" (p.19). He goes further by stating that it "necessarily implicates an intrapsychic conflict between what people think they should be (i.e., heterosexual) and how they experience their own sexuality (i.e., as homosexual or bisexual)" (p.19). Yet, because they did not have problems with all gay individuals, but only with those who were not masculine, it seems that internalized homophobia does not fully express the patterns observed in this study. In fact, it became clear that they did not dislike gay men in general, nor did they feel disgust for who they personally were - they only expressed dislike for effeminate men. What they were expressing, then, was not a feeling of homophobia, nor a feeling of "feminophobia" as they did 
not express in their interview fear and dislike of women, but a feeling "effeminophobia." This term was first coined by Sedgwick (1993), and recently, more fully defined by Richardson (2009) as the fear of effeminacy — a fear widely spread in the Anglo-Saxon culture where "the effeminate man is either, depending upon his context, a figure of fun or a monster to be feared" (p.529). Both of these incarnations, the figure of fun and the monster (to be understood as the one outside the norm), appeared in our informants' comments discussed earlier.

Where does this feeling of "effeminophobia" come from? The answer might have to be found in societal dominant discourses and attitudes toward homosexuality and masculinity. Growing up, informants mentioned being constantly confronted by images of gay men as effeminate in popular culture. This constant representation of gay men reinforces their portrayal as "the Other," the one who is not part of mainstream society (Iglesias-Urquizar, 2009). In fact, growing up in the country, both American and French men mentioned the lack of role models and emphasized the lack of visibility of homosexuality. In rural areas where they grew up, heterosexuality is socially constructed in everyday social interactions whereas homosexuality is left undefined. As a result, most of them apprehended homosexuality as something unreal that only happens "far away." It may exist in cities, but not in their community. When asked how he learned about homosexuality, Sam explained:

Through movies and through TV shows and I think a lot of it too was because of gay jokes. Nobody ever made the joke at me, and it made that thing being so out there, like something they only do on TV, it is made up, it is in the books, it is not real.

Popular culture artifacts—-such as TV shows and movies—-became a major source of information for young men eager to make sense out of their same-sex desires. However, discourses carried by these artifacts, in most cases if not all, did not help young men come to terms with their sexuality. On the contrary, media representations reinforced their state of 
confusion as they did not recognize themselves in these discourses. Usually, they felt confused

by these cultural messages as homosexual characters were portrayed as effeminate, a

characteristic with which none of the informants associated themselves.

Tyler, an American man in his early 30s explained:

I think when I was a kid I only heard about the negative aspects, people thought that those things would only happen in the big cities, and if I saw any representations in a movie or on TV, drag queens or men wearing tight pink things, that was really unappealing to me, and I was like "that's not me, and I don't want that, so how can I be gay?" Until I realized that was just a stereotypical fraction that it was a subculture that doesn't really exist in rural areas as much.

Yannick, a French man in his late 20s, also described his confusion when facing images and representations of homosexuality of TV:

I learned what homosexuality was through television-it was really my window to the rest of the world - with gay pride parades that they were showing. So I discovered homosexuality through gay pride parades you can see on TV. That was always a big moment at home because it gave everyone opportunities to be openly homophobic. For me, gay pride parades were giving a negative image of homosexuality. (...). [What I felt watching gay pride parades] is complicated. I could identify with the whole thing, but the images that were displayed — only men dressed up as women — and these images did not reflect who I was. So, if you like, I could identify myself with the context, but not with the form. I was telling myself that it was not possible; I did not look like that. So, it was complicated because I was thinking that I might be gay, but at the same time I might not be because I don't dress up like a girl.

The only representations that Tyler and Yannick saw on TV growing up associated homosexuality and effeminacy. Their experience reflects that of most gay men interviewed in this study. All of them mentioned being confronted by a single image portraying gay men as effeminate. These images reflect the identification of a dominant discourse in both American and French societies regarding homosexuality that gay men in this study contrasted themselves against. In addition, these images reinforced the feeling of confusion that they experienced. Growing up in the country, gay men experienced unique confusion due to the difficulty to make 
sense of themselves in a heteronormative social context where men had to be masculine and women feminine.

In France, among the different cultural artifacts portraying gay men as effeminate, and then consequently identified as deviant by my informants, was the popular 1978 movie La Cage aux Folles. This movie served to centralize their anger. Michael, a man in his mid-20s explained that the movie "describes gay men as queens. It's a movie that was made a long time ago. The problem with it, is that there are transvestites and people thought that homosexuals are transvestites." For him transvestites — because they are men dressing up and behaving like women—are deviant individuals who should not exemplify what homosexuality is. When asked how this movie could have been made differently to better fit how he views homosexuality, he said: "if they had made a gay movie such as the ones that are made today, it would have been better, because there is no mentioning about transvestite individuals. (...) These new movies portray men in a very manly fashion." For Michael, movies portraying homosexual men as masculine are more appealing and fit better with his quest for not deviating from the norm.

As suggested by Eribon (1999), subscribing to artistic, literary and cinematographic models to build one's homosexual identity can represent a way out of social and family models overwhelmingly shaped by the heterosexual order. However, the discourse that conflates effeminacy and homosexuality existing in these models (or at least the ones they had access to) did not help them to accept and make sense of their desires. This type of representation where effeminacy and homosexuality become intermingled reflects the dominant discourse existing in both French and US societies. As noted by Eribon (1999), in France, and Halperin (2007), in the United States, throughout the 20th century, homosexuality and effeminacy have been conflated in Western ideology. In homophobic discourses as well as in cultural representations, 
homosexual men have constantly been caricatured as effeminate. Among respondents too, this image of "la folle" in France and "the queen" in the United States has been central to this system of representations. Consequently this image is experienced as an imposition, a forced identity (Le Talec, 2008). Accepting their same-sex desires and attractions brings challenges. The existing social analogy between "being homosexual" and "being effeminate" complicate the process of sexual self-acceptance.

"Effeminophobia" does not only originate from popular culture representations, it is also embedded in social interactions and practices. Recently, Pascoe argued that "effeminophobia" is strongly expressed among male teenagers in high school as a mean to assert masculinity. In Dude, You're a Fag (2007), she discusses the figure of the effeminate boy as a source of anxiety for other boys. In fact, she argues that the effeminate boy, by renouncing his masculine privilege and moving down the gender ladder, also reveals to the crowd that gender is not fixed but flexible. For informants in this research, the social anxiety inherent in the "effeminate boy" was a real and immediate part of their youth. For example, Yannick was recalling a particularly painful episode of his teenage years when other boys threw stones at him calling him a "fag," he explained:

This kind of episode only happened once, and this was really the most difficult episode to handle... but most of the time it was comments, and it was always once in a while, but it was always there, always underlying.

For Yannick, these comments constituted a permanent underlying pressure reminding him of his difference and of the threat of effeminacy. When reflecting on his experience in high school, Martin, another American gay man in his mid-30s, explained how he also understood the maintenance of masculine norms in indirect messages as well: 
I got a very strong sense that it was wrong for a boy to [sic] being artistic. Like I said, I just felt pressure that if I was to be accepted I had to act like this, I had to act the way every other boy I knew acted.

When asked how he could tell that it was not appropriate for a boy to be artistic, Martin mentioned that "it was just because of the comments" and how "people were looking at you and speaking about you." Therefore, whether openly stated or not, expressions or behaviors demonstrating effeminacy were clearly coercive and all our informants understood and internalized that message.

However, in their adult lives, some respondents noted that they too have violated masculine norms. Nathan, an American informant in his mid-30s who was a 'real jock' in high school, argued that growing up in a farming community might be the reason for his typical masculine behavior. He explained: "[M]aybe it goes back to growing up in a rural area on a farm, and you know, if you are a gay, you act like a guy." When he was asked to elaborate on this comment he made earlier, he said:

I guess I can't say, I just know that growing up in a rural area, if you-especially when you are going to school - if you had somebody that was a total queen, flaming out, they would not have-especially in a small school like mine where my class was 28 -you wouldn't have had friends if you were a flaming queen, so I think you have a tendency to... but don't get me wrong, give me a few beers and you play It's raining men and I will "queen out."

In this quote, Nathan identifies, again, a source of anxiety inherent in the effeminate boy. However, he perceives his adult behavior as more malleable acknowledging that he is able to "queen out." This acceptance remains qualified nonetheless as it remains in the context of only under the influence of "a few beers." Alcohol, here, provides an avenue to violate the norm. Traditional masculine behavior is therefore not dislodged as a coercive discourse. It remains the guide for Nathan's presentation of self — it is what Nathan "is" when he is himself. 
Growing up in the country, whether it was in their house, at school, or within their rural community, gay men interviewed in the study were confronted by a heterosexual matrix as coined by Butler (1990):

a hegemonic discursive/epistemological model of gender intelligibility that assumes that for bodies to cohere and make sense there must be a stable sex expressed through a stable gender (masculine expresses male, feminine expresses female) that is oppositionally and hierarchically defined through the compulsory practice of heterosexuality. (p. 151)

This heterosexual matrix defines normality regarding gender and sexuality. Following it, normal men were heterosexual and masculine and normal women were heterosexual and feminine. Anyone who would step outside this model would be considered deviant, abnormal, and would have to endure the disapproval of the community. The definition of normality given under the regime of heterosexual hegemony matches the definition of normality given by informants. As suggested in previous studies (see for example Chauncey, 1994), masculine gay men keep the trappings of masculinity, and, consequently, the correspondence between gender and biology follows social norms. In this way, the homosexuality of the research participants, which is not "visible" any longer, becomes only a "potential" stigma. As seen in the previous discussion, all of our informants, both French and American, did not feel different from other men living in the country despite their sexual identity. This sexual identity could represent a first step outside the normality found in the heterosexual matrix. In their childhood, they learned that not the sexuality, but the gender behaviors, provoked anxiety in others and themselves. However, by adopting the attributes of hegemonic masculinity, they are able to step back into the heterosexual matrix (therefore back into "normality"). Thus, their sexual identity does not "betray" them any longer. As seen from our opening vignette, the life stories in this study reflect both the coercive power of the heterosexual matrix, and the resultant pride from the ability to 
follow its strictures on masculinity despite the informants' currently unquestioned sexual identities. In this way, the discursive thread of "effeminophobia", found here across ages and countries, appears to be both cause and consequence of the balance of identities in which they engage.

\section{Conclusion}

Does this strong heterosexual matrix only characterize French and US rural spaces? At this point of the research, answering this question is difficult. If, for example, we look at how our rural participants emphasize their masculinity, even though it appears central to their presentation of self, it is not specific to them. In fact, other studies suggested that gay men in general, not necessarily from a rural background, tend to develop and emphasize masculine behaviors and features. Their goal is to challenge their discredited social status and to go against the idea that they are not real men because of their sexuality (see for example the work of Kimmel and Mahalik, 2004). Therefore, comparing subjectivities and life experiences of gay men who grew up in urban spaces would be necessary to conclude on the specificities of the experiences of rural gay men. In the future, in addition to this comparison, it would be interesting to include the experiences of other LGBTQ individuals. In fact interviewing men belonging to ethnic minorities, men who do not identify themselves as homosexual but who have sex with other men, and women, would bring additional insights and understandings to how this heterosexual matrix impacts on LGBTQ rural individuals.

Without overgeneralizing, we can only argue that this heterosexual matrix exists and has a strong impact on the lives and subjectivities of our informants who grew up in a rural setting. In fact, informants from both nationalities and from different generations explained that growing 
up in the country, heterosexuality was highly visible in different social settings (at home, at school, and at church) where it was socially constructed on a daily basis, whereas homosexuality was invisible and left undefined. Experiencing same-sex attractions and desires resulted in feeling confused, different, and isolated as gay men expressed the lack of role models to build their identity on and to make sense of their feelings. Undoubtedly, these costs are a high price to pay to "fit in" as a man.

\section{References}

Ageron, C-R., \& Dora, P. (1997). Les Lieux de Mémoire: Tome 3. Paris, France : Gallimard.

Andrews, H. (2009). 'Tits Out for the Boys and No Back Chat': Gendered Space on Holiday. Space and Culture, 12, 166-183.

Annes, A., \& Redlin, M. (2011). Coming out and coming back: Rural gay migration and the city, Journal of Rural Studies, in press.

Armbrecht, T. (2005). Can One Be 'Gay' and French? The Gay and Lesbian Review, May-June, 20-22.

Atkinson, R. (2002). The Life Story Interview. In J. Gubrium \& J. Holstein (eds.), Handbook of Qualitative Research (pp.121-140). Thousand Oak, CA: Sage Publication.

Bell, D. (2000). Farm Boys and Wild Men: Rurality, Masculinity, and Homosexuality. Rural Sociology, 65, 547-561.

Bell, D. (2006). Cowboy Love. In H. Campbell, M. Bell, \& M. Finney (eds.) Country Boys: Masculinity and Rural Life (pp.163-182). University Park, PA: Penn State Press.

Bell, D. \& Valentine, G. (1995). Queer Country: Rural Gay and Lesbian Lives. Journal of Rural Studies 15, 113-122.

Blidon, M. (2010). Quartier gay et idéal républicain à la française, un débat mal posé. Bulletin d'histoire politique, 18, 33-42.

Bonfitto, V. (1997). The Formation of Gay and Lesbian Identity and Community in the Connecticut River Valley of Western Massachusetts, 1900-1970. Journal of Homosexuality, 33, 69-96. 
Bunce, M. (1994). The Countryside Ideal: Anglo-American Images of Landscape. New York, NY: Routledge.

Butler, J. (1990). Gender Trouble. Feminism and the Subversion of Identity. New York: Routledge.

Calhoun, C. (1994). Social Theory and the Politics of Identity. Malden, MA: Blackwell Publishers.

Campbell, H. (2000). The glass phallus: Pub(lic) Masculinity and Drinking in Rural New Zealand, Rural Sociology, 65, 562-582.

Campbell, H., Bell, M., \& Finney, M. (2006). Country Boys: Masculinity and Rural Life. University Park, PA: Penn State Press.

Cervulle, M., \& Rees-Roberts, N. (2010). Homo Exoticus. Race, Classe et Critique Queer. Paris, France : Armand Colin.

Charmaz, K. (2006). Constructing Grounded Theory: A Practical Guide Through Qualitative Analysis. London, UK: Sage.

Chauncey, G. (1994). Gay New York: Gender, Urban Culture and the Making of the Gay Male World 1890-1940. London: Flamingo.

Cloke, P. (2005). Conceptualizing Rurality. In P. Cloke, T. Marsden, \& P. Mooney (eds.) Handbook of Rural Studies (pp.18-28). London, UK: Sage Publication.

Cody, P., \& Welch, J. (1997). Rural Gay Men in Northern New England: Life Experiences and Coping Styles. Journal of Homosexuality, 33, 51-67.

Collins, P. (1990). Black Feminist Thought: Knowledge,Consciousness, and the Politics of Empowerment. Boston, MA: UnwinHyman.

Collins, P. (2005). Black Sexual Politics. London, UK: Routledge.

Connell, R. W. (1987). Gender and Power Society, the Person, and Sexual Politics. Standford, CA: Standford University Press.

Connell, R.W. (1992). A Very Straight Gay: Masculinity, Homosexual Experience, and the Dynamic of Gender. American Sociological Review, 57, 735-751.

Connell, R.W. (1995). Masculinities. St. Leonards, Australia: Allen and Unwin.

Corbin, J. \& Strauss, A. (2007). Basics of Qualitative Research: Techniques and Procedures for Developing Grounded Theory. Newbury Park, CA: Sage Publication. 
Crenshaw, K. (1991). Mapping the Margins: Intersectionality, Identity Politics, and Violence against Women of Color. Stanford Law Review, 43, 1241-1299.

D'Augelli A. \& Hart, M. (1987). Gay Women, Men, and Families in Rural Settings: Toward the Development of Helping Communities, American Journal of Community Psychology, 15, 79-93.

Edwards, T. (2006). Cultures of Masculinity. Oxon, UK: Routledge.

Eribon, D. (1999). Réflexion sur la question gay. Paris, France : Fayard.

Fassin, E. (2006). The Rise and Fall of Sexual Politics in the Public Sphere: A Transatlantic Contrast. Public Culture, 18, 79-92.

Fellows, W. (1996). Farm Boys: Lives of Gay Men from the Rural Midwest. Madison, WI: University Of Wisconsin Press.

Floyd, F. \& Bakeman, R. (2006). Coming-Out Across the Life Course: Implication of Age and Historical Context. Archives of Sexual Behaviors, 35, 287-296.

Forsyth, A. (1997). Out in the Valley. International Journal of Urban and Regional Research, $21,38-62$.

Forsyth, A. (2001). Sexuality and Space: Nonconformist Populations and Planning Practice. Journal of Planning Literature, 15, 339-359.

Glaser, B., \& Strauss, A. (2006). The Discovery of Grounded Theory: Strategies for Qualitative Research., New Brunswick, NJ: AldineTransaction.

Gray, M. (2009). Out in the Country: Youth, Media, and Queer Visibility in Rural America. New York, NY: NYU Press.

Halperin, D. (2007). What do Gay Men Want? Ann Arbor, MI: University Press of Michigan.

Haraway, D. (1988). Situated Knowledge: The Science Question in Feminism and the Privilege of Partial Perspectives. Feminist Research, 14, 575-599.

Hearn, J., \& Morgan, D. (1990). Men, Masculinities and Social Theory. London, UK: Routledge.

Herek, G. M. (2004). Beyond "homophobia": Thinking about sexual prejudice and stigma in the twenty-first century. Sexuality Research and Social Policy, 1, 6-24.

Hockey, J., Meah, A., \& Robinson, V. (2007). Mundane Heterosexualities: From Theory to Practices. London, UK: Palgrave. 
Howard, J. (1999). Men Like That: A Southern Queer History. Chicago, IL: University of Chicago Press.

Iglesias-Urquizar, J. (2009). Man or Mouse?: Representations of Masculinity in American Television and Film, 1998-2008. M.A. Thesis, South Dakota State University, Department of English.

Inness, S., (2004). Lost in Space: Queer Geography and the Politics of Location. In:D. Carlin, \& J. DiGrazia (Eds.) Queer Cultures (pp. 254-277). Upper Saddle River, CA: Pearson.

Johnstone, C. (2008). (Post-)Queer Citizenship in Contemporary Republican France. Contemporary French and Francophone Studies, 12, 89-97.

Kennedy, M. (2010). Rural Men, Sexual Identity and Community. Journal of Homosexuality, 57, 1051-1091.

Kimmel, M. (1987). Changing Men: New Directions in Research on Men and Masculinity. Newbury Park, CA: Sage Publications.

Kimmel S., \& Mahalik J. (2004). Measuring masculine body ideal distress: Development of a measure. International Journal of Men's Health, 3, 1-10.

Kramer, J-L. (1995). Bachelor Farmers and Spinsters: Gay and Lesbian Identities and Communities in Rural North Dakota. In D. Bell, \& G. Valentine (eds.). Mapping Desire: Geographies of Sexualities (pp. 200-213). London, UK: Routledge.

Lancaster, R. (2006). Sex, Science, and Pseudoscience. Identities, 13, 101-106.

Le Talec, J.Y. (2008). Folles de France: Repenser l'homosexualité masculine. Paris, France : Edition La Découverte.

Lipsitz, G. (2006). How White People Profit from Identity Politics. Philadelphia, PA: Temple University.

Little, J. (2002). Gender and Rural Geography. London, UK: Pearson.

Little, J. (2003). 'Riding the rural love train': Heterosexuality and the rural community. Sociologia Ruralis, 43, 401-417.

Little, J., \& Panelli, R. (2007). Outback"Romance? A Reading of Nature and Heterosexuality in Rural Australia. Sociologia Ruralis, 47,173-186.

Lobao, L. (2006). Gendered Places and Place-Based Gender Identities: Reflections and refractions. In H. Campbell, M. Bell, \&M. Finney (eds.) Country Boys: Masculinity and Rural Life (pp. 267-276). University Park, PA: Penn State Press. 
Loffreda, B. (2000). Losing Matt Shepard: Life and Politics in the Aftermath of Anti-Gay Murder. New York, NY: Columbia University Press.

Martel, F. (1999). The Pink and the Blacks: Homosexuals in France since 1968. Palo Alto, CA: Stanford Press University.

McCall, L. (2005). The Complexity of Intersectionality. Signs, 30, 1771-1801.

Moses, A.E., \& Hawkins, R. (1980). The Special Problems of Rural gay Clients. Human Services in the Rural Environment, 5, 22-27.

Noy, C. (2008). Sampling Knowledge: The Hermeneutics of Snowball Sampling in Qualitative Research. International Journal of Social Research Methodology, 11, 327-344.

Pascoe, C.J. (2007). Dude, You're a Fag: Masculinity and Sexuality in High School. Berkeley, CA: University of California Press.

Reumann, M. ( 2006). American Sexual Character: Sex, Gender, and National Identity in the Kinsey Reports. Berkeley, CA: University of California.

Richardson, N. (2009). Effeminophobia, Misoginy and Queer Friendship: The Cultural Themes of Channel 4's Playing It Straight. Sexualities, 12, 525-544.

Robinson, V. (2008). A Different Kind of Hard: Everyday Masculinities, Identity and Rock Climbing. Oxford, UK: Berg Publishers.

Rubin, G. (1984). Thinking Sex: Notes for a Radical Theory of the Politics of Sexuality. In. C. Vance (ed.) Pleasure and Danger: Exploring Female Sexuality (pp. 143-179). London, UK: Routledge \&Kegan Paul.

Sasson-Levy, O. (2002). Constructing Masculinities at the Margins: Masculinities and Citizenship in the Israeli Army. Sociological Quarterly, 43,357-383.

Saugeres, L. (2002). The Cultural Representation of the Farming Landscape: Masculinity, Power and Nature. Journal of Rural Studies 18, 373-384.

Sedgwick, E. (1991). How to Bring Your Kids Up Gay. Social Text, 29, 18-27.

Tin, L-G. (2008). L'Invention de la Culture Hétérosexuelle. Paris, France : Éditions Autrement.

Warren, C. (2002). Qualitative Interviewing. In J. Gubrium and J. Holstein (eds) Handbook of Qualitative Research(pp. 83-102). Thousand Oak, CA: Sage Publication. 